\title{
PENERAPAN PROBLEM BASED LEARNING (PBL) MENINGKATKAN HASIL BELAJAR KIMIA
}

\author{
UMI SUSWATI \\ SMAN 1 Purwanegara \\ Email : umisuswati05@gmail.com
}

\begin{abstract}
ABTRAK
Tujuan penelitian ini adalah untuk mengkaji dan mendeskripsikan penerapan model pembelajaran Problem Based Learning (PBL) sebagai salah satu metode untuk meningkatkan hasil belajar kimia. Penelitian kualitatif ini menggunakan metode literatur review yaitu mencari referensi teori yang relefan dengan kasus atau permasalahan dengan cara menelusuri sumbersumber tulisan yang pernah dibuat sebelumnya. Teknik analisis data sekunder menggunakan pendekatan deskriptif kuantitatif, berupa data hasil belajar siswa pada mata pelajaran Kimia. Teknik pengumpulan data adalah dokumentasi yaitu melacak sumber tertulis yang berisi berbagai tema dan topik yang dibahas. Sumber data berasal dari buku, artikel jurnal online, internet, seminar, hasil penelitian, dan data yang berkaitan dengan materi penelitian. Penelitian dilakukan dengan cara menganalisis data keterkaitan antara penerapan model Problem Based Learning (PBL) dengan hasil belajar siswa pada mata pelajaran Kimia. Hasil penelitian menunjukkan bahwa penerapan model Problem Based Learning (PBL) dapat meningkatkan hasil belajar kimia.
\end{abstract}

Kata Kunci: Problem Based Learning, Hasil Belajar Kimia

\section{PENDAHULUAN}

Pelajaran kimia merupakan salah satu bagian dari Ilmu Pengetahuan Alam (IPA). Ilmu kimia merupakan ilmu yang mempelajari struktur materi, sifat-sifat materi, perubahan suatu materi menjadi materi lain, serta energi yang menyertai perubahan materi. Hakekat ilmu kimia mencakup dua hal yang tidak terpisahkan, yaitu kimia sebagai produk dan kimia sebagai proses. Kimia sebagai produk meliputi sekumpulan pengetahuan yang terdiri atas fakta-fakta, konsepkonsep, dan prinsip-prinsip yang dimiliki oleh para ilmuwan untuk memperoleh dan mengembangkan pengetahuan kimia. Kimia sebagai proses meliputi keterampilanketerampilan dan sikap-sikap yang dimiliki oleh para ilmuwan untuk memperoleh dan mengembangkan pengetahuan kimia.

Masalah yang menarik untuk diperhatikan tentang ilmu kimia adalah banyak memberi manfaat dalam kehidupan manusia, tetapi banyak fakta menunjukkan bahwa ilmu kimia dipandang sebagai ilmu yang sulit dan tidak menarik untuk dipelajari. Menurut Wiseman dalam Suarsani (2019) menyatakan pendapatnya bahwa ilmu kimia merupakan salah satu mata pelajaran yang mempunyai tingkat kesulitan tinggi bagi kebanyakan siswa menengah, kesulitan mempelajari ilmu kimia terkait dengan ciri-ciri ilmu kimia itu sendiri. Jika siswa tersebut tidak memiliki potensi yang baik dalam bidang kimia, maka siswa tersebut mengalami kesulitan dalam belajar mata pelajaran kimia.

Karakteristik ilmu kimia adalah sebagai ilmu pengetahuan alam yang membutuhkan contoh konkrit yang ada di sekitar dan metode ilmiah yang memiliki rangkaian proses ilmiah demi memperoleh konsep, hukum, aturan dan prinsip ilmiah. Dalam proses pembelajaran kimia, masih banyak siswa yang merasa kesulitan dalam pemecahan masalah, dalam mengaitkan konsep kimia dengan teori-teori dengan benar. Masih banyak siswa yang terjebak dengan rumus tanpa memahami konsepnya. Hal tersebut mengakibatkan hasil belajar kimia masih rendah.

Beberapa penelitian menjelaskan bahwa rendahnya hasil belajar pada beberapa konsep kimia, dipengaruhi oleh beberapa faktor, antara lain: (1) siswa merasa sulit memahami konsep kimia yang bersifat abstrak serta gabungan antara pemahaman konsep dan aplikasi, (2) siswa merasa sulit menerapkan teori-teori kimia, (3) siswa kurang termotivasi untuk belajar kimia, 
dan (4) ada sebagian besar siswa yang menganggap kimia sebagai pelajaran yang sulit. Materi kimia yang dibahas dalam penelitian misalnya pada konsep Ikatan Kimia, Larutan Asam-Basa, Kimia Unsur, Kesetimbangan Kimia, Sistem Koloid, Larutan Penyangga, dan Stoikiometri Larutan

Disamping itu, dalam proses belajar mengajar, guru memegang peranan penting dalam mencapai tujuan pembelajaran, namun kenyataan dalam proses pembelajaran masih menggunakan model konvensional dan pendekatan yang berpusat pada guru (teacher centered learning), tidak menggunakan media pembelajaran sehingga kurang menarik perhatian siswa, kurang memberikan motivasi dan memberi kesempatan siswa untuk partisipasi aktif, dan sering memposisikan siswa sebagai objek belajar, bukan sebagai individu yang harus dikembangkan potensinya.

Melihat kondisi tersebut, maka guru mencari alternatif untuk memecahkan maasalah pembelajaran kimia. Guru mencari solusi untuk meningkatkan hasil belajar kimia, baik secara individu maupun klasikal dengan mendesain kegiatan belajar mengajar yang lebih mengaktifkan guru dan siswa melalui pendekatan ilmiah. Salah satu model pembelajaran yang menggunakan pendekatan ilmiah yang mendorong siswa mampu mengamati, menanya, mengasosiasi dan mengkomunikasikan adalah model pembelajaran Problem Based Learning (PBL). Menurut Harsono dalam Suprihatiningrum (2013: 216) menyatakan bahwa PBL bertujuan agar siswa mampu memperoleh dan membentuk pengetahuannya secara efisien, kontekstual, dan terintegritas untuk membantu siswa mengembangkan keterampilan berpikir, keterampilan intelektual, dan keterampilan menyelesaikan masalah.

\section{MODEL PROBLEM BASED LEARNING (PBL)}

Model pembelajaran Problem Based Learning (PBL) membantu guru menciptakan lingkungan pembelajaran yang dimulai dengan masalah penting dan relevan bagi siswa, dan memungkinkan siswa memperoleh pengalaman belajar yang lebih.

Menurut Arend dalam Suprihatiningrum (2013: 215), menyatakan bahwa PBL merupakan suatu pendekatan pembelajaran di mana siswa dihadapkan pada masalah autentik atau nyata sehingga diharapkan mereka dapat menyusun pengetahuannya sendiri, menumbuhkembangkan keterampilan tingkat tinggi dan inkuiri, memandirikan siswa, dan meningkatkan kepercayaan dirinya. Siswa dihadapkan pada suatu masalah yang kemudian diikuti oleh proses pencarian informasi yang bersifat student centered.

Menurut Glazer dalam Suarsani (2019) menyatakan bahwa PBL menekankan belajar sebagai proses yang melibatkan pemecahan masalah dan berpikir kritis dalam konteks yang sebenarnya. Melalui PBL siswa memperoleh pengalaman dalam menangani masalah-masalah realistis, dan menekankan pada penggunaan komunikasi, kerja sama dan sumber-sumber yang ada untuk merumuskan ide dan mengembangkan keterampilan penalaran.

Menurut Barrow dalam Yani (2020) menjelaskan enam ciri khusus dari PBL, yaitu, (1) pembelajaran berpusat pada siswa, (2) pembelajaran terjadi dalam kelompok kecil siswa, (3) guru berperan sebagai fasilitator, (4) masalah merupakan fokus dan stimulus dalam pembelajaran, (5) masalah merupakan jalan untuk pengembangan kemampuan pemecahan masalah secara klinis, dan (6) informasi baru diperoleh melalui pembelajaran yang mengarahkan diri.

Menurut Ibrahim dalam Suprihatiningrum (2013: 223) menjelaskan bahwa ada lima langkah utama yang dimulai dari guru memperkenalkan siswa dengan suatu masalah, diakhiri dengan penyajian dan analisis hasil kerja siswa. Kelima langkah tersebut berikut ini:

Tahap-1: Orientasi siswa pada masalah. Guru menjelaskan tujuan pembelajaran, menjelaskan logistik yang dibutuhkan, mengajukan fenomena, demonstrasi, atau cerita untuk memunculkan masalah, memotivasi siswa untuk terlibat dalam pemecahan masalah yang dipilih.

Tahap-2: Mengorganisasikan siswa untuk belajar. Guru membantu siswa untuk mendefinisikan dan mengorganisasikan tugas belajar yang berhubungan dengan masalah tersebut. 
Tahap-3: Membimbing penyelidikan individual atau kelompok. Guru mendorong siswa untuk mengumpulkan informasi yang sesuai, melaksanakan eksperimen untuk mendapatkan penjelasan dan pemecahan masalah.

Tahap-4: Mengembangkan dan menyajikan hasil karya. Guru membantu siswa dalam merencanakan dan menyiapkan karya yang sesuai, seperti laporan, video dan model serta membantu merekan untuk berbagi tugas dengan temannya.

Tahap-5: Menganalisis dan mengevaluasi proses pemecahan masalah. Guru membantu siswa melakukan refleksi atau evaluasi terhadap penyelidikan mereka dan proses-proses yang mereka gunakan.

Beberapa kecakapan dan sikap yang harus dimiliki siswa dalam penerapan PBL adalah kerja sama dalam kelompok dan di luar diskusi kelompok, mendengarkan pendapat teman, mencatat hal-hal yang didiskusikan, menghargai pendapat teman, bersikap kritis terhadap literatur, belajar secara mandiri, mampu menggunakan sumber belajar secara efektif, dan keterampilan presensi.

\section{Hasil Belajar}

Belajar diartikan sebagai perubahan tingkah laku pada diri induvidu berkat adanya interaksi antara individu dan individu dengan lingkungannya. Dalam Sardiman (2012) dijelaskan bahwa tujuan belajar ada tiga jenis, yaitu (1) untuk mendapatkan pengetahuan, (2) penanaman konsep dan keterampilan, dan (3) pembentukan sikap. Menurut Dewey dalam Sumiati (2018) menyatakan belajar berdasarkan masalah adalah interaksi antara stimulus dengan respons, merupakan hubungan antara dua arah belajar dan lingkungan.

Proses belajar mengajar merupakan suatu proses yang mengandung serangkaian perbuatan guru dan siswa atas dasar hubungan timbal balik yang berlangsung dalam situasi edukatif untuk mencapai tujuan tertentu. Interaksi atau hubungan timbal balik antara guru dan siswa merupakan syarat utama bagi berlangsungnya proses belajar mengajar. Proses belajar adalah kegiatan yang dilakukan oleh siswa dalam mencapai tujuan pengajaran. Menurut Bruce Well dalam Yani (2020) mengemukakan tiga prinsip dalam proses pembelajaran, yaitu: (1) proses pembelajaran adalah bentuk kreasi lingkungan yang dapat membentuk atau mengubah struktur kognitif siswa, (2) berhubungan dengan tipe pengetahuan yang masing-masing memerlukan situasi berbeda dalam mempelajarinya, yaitu: sosial, fisis, dan logika, dan (3) dalam pembelajaran harus melibatkan peran lingkungan sosial. Lingkungan sosial dapat membentuk anak untuk berinteraksi, berkomunikasi, dan berbagi pengalaman yang memungkinkan mereka berkembang secara nyata.

Hasil belajar adalah kemampuan-kemampuan yang dimiliki siswa setelah menerima pengalaman belajar. Hasil belajar juga merupakan hasil dari proses belajar berupa perubahan tingkah laku pada individu yang telah melalui tahap belajar. Perubahan tingkah laku tersebut menyangkut perubahan yang bersifat pengetahuan (kognitif), keterampilan (psikomotor) maupun nilai dan sikap (afektif). Oleh karena itu, apabila siswa mempelajari pengetahuan tentang konsep, maka perubahan perilaku yang diperoleh tidak hanya berupa penguasaan konsep tetapi juga keterampilan dan sikap.

Hasil belajar siswa dapat diketahui melalui penilaian kelas. Penilaian kelas merupakan proses pengumpulan dan penggunaan informasi untuk pemberian keputusan terhadap hasil belajar siswa. Berdasarkan tahapan kemajuan belajarnya akan didapatkan potret atau profil kemampuan siswa sesuai dengan kompetensi yang ditetapkan dalam kurikulum. Bentuk penilaian kelas yang digunakan berupa penilaian kinerja (perfomance), penilaian tes tertulis (paper and pen), dan penilaian sikap.

\section{METODE PENELITIAN}

Penelitian ini bertujuan untuk mengkaji dan mendeskripsikan penerapan model pembelajaran Problem Based Learning (PBL sebagai salah satu metode untuk meningkatkan hasil belajar kimia pada beberapa konsep kimia di jenjang SLTA, baik SMA, SMK, dan MA. 
Metode yang digunakan adalah studi literatur (literatur review) atau studi kepustakaan, yaitu mencari referensi teori yang relefan dengan kasus atau permasalahan dengan cara menelusuri sumber-sumber tulisan yang pernah dibuat sebelumnya. Literatur review berisi uraian tentang teori temuan dan bahan penelitian lain yang diperoleh dari bahan acuan untuk dijadikan landasan kegiatan penelitian.

Teknik pengumpulan data yang digunakan adalah dokumentasi, yaitu melacak sumber tertulis yang berisi berbagai tema dan topik yang dibahas. Sumber tersebut berupa buku, artikel jurnal online, internet, seminar, hasil penelitian, maupun data yang berkaitan dengan materi penelitian. Dalam mencari data menggunakan kata kunci Problem Based Learning (PBL) dan Hasil Belajar Kimia. Teknik analisis data yang digunakan adalah deskriptif kuantitatif yang berupa data hasil belajar siswa pada mata pelajaran Kimia. Teknik ini memfokuskan pada beberapa literatur yang relevan. Data yang dikumpulkan berupa data sekunder. Data tersebut kemudian diolah, dianalisis, dan disarikan menjadi narasi yang menjelaskan hasil dan kesimpulan tentang penerapan model pembelajaran Problem Based Learning (PBL) yang dapat meningkatkan hasil belajar siswa pada mata pelajaran Kimia.

\section{HASIL DAN PEMBAHASAN}

\section{Hasil}

Dari penelusuran melalui literatur review pada beberapa hasil penelitian yang relevan mengenai penerapan model pembelajaran Problem Based Learning (PBL) dan hasil belajar siswa pada mata pelajaran Kimia, didapatkan dua laporan Penelitian Tindakan Kelas (PTK), satu makalah seminar, dan enam artikel ilmiah untuk dianalisis. Analisis tentang penerapan PBL untuk meningkatkan hasil belajar siswa pada mata pelajaran Kimia terdapat dalam tabel berikut ini:

Tabel 1 Analisis Penerapan Model Problem Based Learning (PBL) Meningkatkan Hasil Belajar Kimia

\begin{tabular}{|c|c|c|c|c|}
\hline No & Nama Penulis & Judul Penelitian & Metode Penelitian & Instrumen \\
\hline 1 & $\begin{array}{l}\text { Linda Reza } \\
\text { Yani, } 2020\end{array}$ & \begin{tabular}{lr} 
Penerapan & Model \\
Pembelajaran & PBL \\
untuk & Meningkatkan \\
Hasil Belajar & Siswa \\
pada Materi & Ikatan \\
Kimia di SMA Negeri 5 \\
\multicolumn{2}{l}{ Takengon }
\end{tabular} & $\begin{array}{l}\text { PTK, dengan teknik } \\
\text { pengumpulan data } \\
\text { melalui observasi, } \\
\text { angket, dan tes. } \\
\text { Teknik analisis data dari } \\
\text { data aktivitas guru dan } \\
\text { siswa }\end{array}$ & $\begin{array}{l}\text { RPP, LKPD, } \\
\text { Lembar } \\
\text { observasi, } \\
\text { angket, soal } \\
\text { tes, dan } \\
\text { sumber belajar. }\end{array}$ \\
\hline 2 & $\begin{array}{l}\text { Baeduriyah, } \\
2020\end{array}$ & $\begin{array}{l}\text { Penerapan Problem } \\
\text { Based Learning } \\
\text { Berbasis TPACK untuk } \\
\text { Meningkatkan Hasil } \\
\text { Belajar Siswa Kelas X } \\
\text { SMKN } 3 \text { Mataram pada } \\
\text { Pokok Bahasan Ikatan } \\
\text { Kimia }\end{array}$ & $\begin{array}{l}\text { PTK, dengan teknik } \\
\text { pengumpulan data } \\
\text { menggunakan tes, lembar } \\
\text { observasi, dan angket } \\
\text { siswa. }\end{array}$ & $\begin{array}{l}\text { RPP, LKPD, } \\
\text { lembar } \\
\text { observasi guru } \\
\text { dan siswa, soal } \\
\text { tes, rubrik } \\
\text { keterampilan } \\
\text { diskusi, dan } \\
\text { sumber belajar. }\end{array}$ \\
\hline 3 & Jami, 2020 & $\begin{array}{l}\text { Meningkatkan Hasil } \\
\text { Belajar Kimia Kelas XI } \\
\text { MIA MAN } 1 \text { Tanjung } \\
\text { Jabung Timur dengan } \\
\text { Menerapkan Model } \\
\text { pembelajaran Problem } \\
\text { Based Learning }\end{array}$ & $\begin{array}{l}\text { PTK, dengan teknik } \\
\text { observasi dan tes. }\end{array}$ & $\begin{array}{l}\text { RPP, lembar } \\
\text { observasi guru } \\
\text { dan siswa, soal } \\
\text { tes, dan } \\
\text { sumber belajar. }\end{array}$ \\
\hline
\end{tabular}


Vol. 1. No. 3 September 2021 e-ISSN : 2775-7188 | p-ISSN : 2775-717X

\begin{tabular}{|c|c|c|c|c|}
\hline 4 & $\begin{array}{l}\text { Gusti Ayu } \\
\text { Suarsani, } \\
2019\end{array}$ & $\begin{array}{l}\text { Meningkatkan Hasil } \\
\text { Belajar Kimia dengan } \\
\text { Materi Pokok Kimia } \\
\text { Unsur Melalui } \\
\text { Penerapan Model } \\
\text { Pembelajaran Problem } \\
\text { Based Learning }\end{array}$ & $\begin{array}{l}\text { PTK, dengan teknik } \\
\text { observasi, tes, } \\
\text { dokumentasi dan } \\
\text { wawancara }\end{array}$ & $\begin{array}{l}\text { RPP, lembar } \\
\text { observasi } \\
\text { siswa, dan } \\
\text { guru.soal tes, } \\
\text { dan sumber } \\
\text { belajar. }\end{array}$ \\
\hline 5 & $\begin{array}{l}\text { Sumiati, } \\
2018\end{array}$ & $\begin{array}{l}\text { Peningkatan motivasi } \\
\text { dan Hasil Belajar dalam } \\
\text { Pembelajaran Kimia } \\
\text { Melalui Penerapan } \\
\text { Model Pembelajaran } \\
\text { Problem Based } \\
\text { Learning (PBL) }\end{array}$ & $\begin{array}{l}\text { PTK, teknik } \\
\text { pengumpulan data } \\
\text { dengan cara triangulasi, } \\
\text { analisis data bersifat } \\
\text { induktif, dan hasil } \\
\text { penelitian menekankan } \\
\text { makna. Penyajian data } \\
\text { dengan pola diskriptif. } \\
\text { Strategi penelitian } \\
\text { dengan model siklus. }\end{array}$ & $\begin{array}{l}\text { RPP, lembar } \\
\text { observasi guru } \\
\text { dan siswa, soal } \\
\text { tes, angket } \\
\text { wawancara, } \\
\text { dan sumber } \\
\text { belajar. }\end{array}$ \\
\hline 6 & $\begin{array}{l}\text { Luki Yunita, } \\
\text { Rifa } \\
\text { Kusmiati, } \\
\text { Nina Afria D, } \\
2016\end{array}$ & $\begin{array}{l}\text { Upaya Meningkatkan } \\
\text { Hasil belajar Kimia } \\
\text { Siswa Melalui Problem } \\
\text { Based Learning pada } \\
\text { Konsep Sistem Koloid }\end{array}$ & $\begin{array}{l}\text { PTK, dengan pendekatan } \\
\text { kualitatif }\end{array}$ & $\begin{array}{l}\text { RPP, LKS, } \\
\text { lembar } \\
\text { observasi guru } \\
\text { dan siswa, } \\
\text { kuesioner, dan } \\
\text { soal tes, dan } \\
\text { sumber belajar. }\end{array}$ \\
\hline 7 & $\begin{array}{l}\text { Apriyani } \\
\text { Puspadewi } \\
\text { dan } \\
\text { Syahmani, } \\
2016\end{array}$ & $\begin{array}{l}\text { Meningkatkan Hasil } \\
\text { Belajar Siswa dengan } \\
\text { Model Pembelajaran } \\
\text { Problem Based } \\
\text { Learning (PBL) } \\
\text { Berbantuan Modul } \\
\text { dalam Materi Larutan } \\
\text { Penyangga }\end{array}$ & $\begin{array}{l}\text { PTK dengan teknik } \\
\text { analisis diskriptif } \\
\text { kuantitatif dan kualitatif. } \\
\text { Teknik pengumpulan } \\
\text { data melalui observasi, } \\
\text { tes hasil belajar dan } \\
\text { angket. }\end{array}$ & $\begin{array}{l}\text { RPP, lembar } \\
\text { observasi guru } \\
\text { dan siswa, } \\
\text { sumber belajar } \\
\text { Modul. }\end{array}$ \\
\hline 8 & $\begin{array}{l}\text { Rohana Putri } \\
\text { Agustina, } \\
\text { Ashadi, Bakti } \\
\text { Mulyana, } \\
2015\end{array}$ & $\begin{array}{l}\text { Penerapan Problem } \\
\text { Based Learning (PBL) } \\
\text { dengan Penilaian } \\
\text { portofolio untuk } \\
\text { Meningkatkan Sikap } \\
\text { Ilmiah dan Prestasi } \\
\text { belajar Siswa pada } \\
\text { Materi Sistem Koloid } \\
\text { kelas XI MIA SMA } \\
\text { Negeri 1 Sukoharjo } \\
\text { Tahun Pelajaran } \\
\text { 2015/2016 }\end{array}$ & $\begin{array}{l}\text { PTK dengan teknik } \\
\text { pengumpulan data tes } \\
\text { dan non-tes (observasi, } \\
\text { wawancara, kajian } \\
\text { dokumen dan angket). } \\
\text { Analisis data kualitatif } \\
\text { dengan teknik analisis } \\
\text { kualitatif (reduksi data, } \\
\text { penyajian data, penarikan } \\
\text { kesimpulan dan } \\
\text { verifikasi. Teknik } \\
\text { validasi data dengan } \\
\text { triangulasi teknik. }\end{array}$ & $\begin{array}{l}\text { RPP, lembar } \\
\text { observasi guru } \\
\text { dan siswa, } \\
\text { angket, } \\
\text { wawacara, soal } \\
\text { tes, dan } \\
\text { sumber belajar. }\end{array}$ \\
\hline 9 & $\begin{array}{l}\text { Pritha } \\
\text { Ariyanti, Kus } \\
\text { Sri Martini, } \\
\text { Widiastuti } \\
\text { Agustina E.S, } \\
2013\end{array}$ & $\begin{array}{l}\text { Penerapan Problem } \\
\text { Based Learning (PBL) } \\
\text { dengan Penilaian } \\
\text { portofolio untuk } \\
\text { Meningkatkan } \\
\text { Keaktifan dan Prestasi } \\
\text { Belajar pada Materi }\end{array}$ & $\begin{array}{l}\text { PTK, dengan teknik } \\
\text { pengumpulan data tes } \\
\text { dan non-tes (observasi, } \\
\text { wawancara, kajian } \\
\text { dokumne, angket). } \\
\text { Teknis analisis data }\end{array}$ & $\begin{array}{l}\text { RPP, lembar } \\
\text { observasi guru } \\
\text { dan siswa, } \\
\text { angket, soal } \\
\text { tes, portofolio, }\end{array}$ \\
\hline
\end{tabular}




\begin{tabular}{|l|l|l|l|}
\hline & $\begin{array}{l}\text { Stoikiometri di SMA N } \\
\text { 2 Surakarta Tahun } \\
\text { Ajaran 2013/2014 }\end{array}$ & $\begin{array}{l}\text { secara deskriptif } \\
\text { kualitatif dan kuantitaif. }\end{array}$ & \\
\hline
\end{tabular}

Berdasarkan kajian beberapa penelitian yang relevan tersebut, guru melakukan Penelitian Tindakan Kelas (PTK) untuk mengetahui pengaruh penerapan model PBL terhadap peningkatan hasil belajar kimia. Pelaksanaannya menggunakan model Kemmis dan Mc Taggart atau John Elliot yang terdiri dari empat tahap penelitian, yaitu perencanaan, pelaksanaa, observasi dan refleksi dengan beberapa siklus berulang. Setelah guru melakukan tahap-tahap penelitian dan menganalisis data dengan cara membandingkan hasil penelitian pada tiap siklusnya, akhirnya dapat membuktikan bahwa, penerapan model pembelajaran PBL dapat meningkatkan hasil belajar siswa pada mata pelajaran Kimia.

Hasil Penelitian Tindakan Kelas (PTK) dengan tiga siklus tindakan oleh Yani (2020) dengan judul Penerapan Model Pembelajaran PBL untuk Meningkatkan Hasil Belajar Siswa pada Materi Ikatan Kimia di SMA Negeri 5 Takengon menyatakan bahwa hasil belajar siswa yang berjumlah 30 siswa pada materi Ikatan Kimia mengalami peningkatan setelah diterapkan model pembelajaran PBL. Pada siklus I hasil belajar siswa mencapai 60\% dengan rata-rata nilai 69,53 , dan mengalami kenaikan pada siklus II menjadi 76,67\% dengan rata-rata nilai 75,4, kemudian naik lagi pada siklus III menjadi $88,66 \%$ dengan rata-rata nilai 80,86 . Kriteria ketuntasan belajar klasikal mencapai 80\%. Dari 30 siswa, sebanyak 27 siswa atau 90\% yang menyukai pembelajaran model PB. Untuk pemahaman materi Ikatan Kimia ada 28 siswa atau 93,33\% menyatakan "ya" karena siswa merasa lebih mudah memahami materi pelajaran dengan kerja sama dalam kelompok. Ada 26 siswa atau 86,67\% menyatakan mampu memecahkan permasalahan yang diberikan oleh guru. Ada 28 siswa atau 93,33\% siswa merasakan medapatkan pengalaman baru. Selanjutnya ada 29 siswa atau 96,67\% siswa menyatakan senang menggunakan model pembelajaran PBL. Ada 27 siswa atau 90\% menyatakan bahwa model pembelajaran PBL dapat membuat siswa lebih aktif dalam proses pembelajaran. Ada 27 siswa atau 93,33\% siswa merasa lebih mandiri belajar Ikatan Kimia dengan menggunakan model PBL. Aktivitas guru dalam melaksanakan model PBL mengalami peningkatan dari siklus I sebanyak $89,17 \%$, naik mwnjadi $95 \%$ pada siklus II dan naik lagi menjadi 96,67\% pada siklus III. Penerapan model PBL di kelas sangat menarik dan tepat karena dapat meningkatkan kemampuan berpikir kritis siswa, menumbuhkan inisiatif siswa dalam bekerja, motivasi internal dalam belajar, dan dapat mengembangkan hubungan interpersonal dalam bekerja kelompok. Dari data terlihat bahwa aktifitas guru, aktivitas siswa, respon siswa, dan hasil belajar siswa meningkat. Dari uraian tersebut, dapat disimpulkan bahwa penerapan model PBL dapat meningkatkan hasil belajar siswa pada mata pelajaran Kimia pada materi Ikatan Kimia.

Penelitian berikutnya oleh Baeduriyah (2020) dengan judul Penerapan Problem Based Learning Berbasis TPACK untuk Meningkatkan Hasil Belajar Siswa Kelas X SMKN 3 Mataram pada Pokok Bahasan Ikatan Kimia. Penelitian tersebut menyatakan bahwa keterlibatan dan hasil belajar Kimia pada konsep Ikatan Kimia.dengan menerapkan model PBL berbasis TPACK di kelas X SMK Negeri 3 Mataram yang berjumlah 33 siswa pada ranah kognitif mencapai ketuntasan klasikal 50\% dengan rata-rata nilai 49 pada siklus I, 50\% dengan rata-rata nilai 63 pada siklus II, dan 66,7\% dengan rata-rata nilai 61 pada siklus III. Pada ranah keterampilan mencapai ketuntasan klasikal yaitu 67\% dengan rata-rata nilai 71 pada siklus I, dan sebesar $80 \%$ dengan rata-rata nilai 75 pada siklus II, dan $86,7 \%$ dengan rata-rata nilai 77,3 pada siklus III. Dari hasil penelitian tersebut dapat disimpulkan bahwa penerapan model PBL dapat meningkatkan keterlibatan dan hasil belajar siswa pada mata pelajaran Kimia pada konsep Ikatan Kimia.

Penelitian selanjutnya oleh Jami (2020) terdapat dalam artikel ilmiah dengan judul Meningkatkan Hasil Belajar Kimia Kelas XI MIA MAN 1 Tanjung Jabung Timur dengan Menerapkan Model pembelajaran Problem Based Learning. Hasil penelitian dengan dua siklus 
menunjukkan bahwa siswa yang mengalami tuntas belajar Kimia pada konsep Asam dan Basa. sebanyak 14 siswa atau 51,85\% dengan perolehan nilai rata-rata 71,26 pada siklus I, dan naik menjadi 21 siswa atau 85,19\% dengan perolehan nilai rata-rata sebesar 81,52 pada siklus II. Kesuliatan belajar siswa yang berasal dari faktor intern dan ekstern dapat diatasi dengan menerapkan moldel PBL. Berdasarkan hasil penelitian tersebut maka dapat disimpulkan bahwa penerapan model PBL dapat meningkatkan keterlibatan dan hasil belajar siswa pada mata pelajaran Kimia pada konsep Asam Basa..

Penelitian berikutnya oleh Suarsani (2019) dalam artikel ilmiahnya dengan judul Meningkatkan Hasil Belajar Kimia dengan Materi Pokok Kimia Unsur Melalui Penerapan Model Pembelajaran Problem Based Learning. Hasil penelitian dengan dua siklus tersebut menunjukkan bahwa penerapan model pembelajaran PBL berhasil meningkatkan hasil belajar Kimia pada konsep Kimia Unsur di kelas XII MIPA A4 SMAN Negeri 1 Ubud tahun pelajaran 2016/2017. Ketuntasan hasil belajar pada siklus I sebesar 77,63\% naik menjadi $79,6 \%$ pada siklus II. Penerapan PBL yang dipadukan dengan praktikum mampu mendorong siswa lebih aktif dalam pemecahan masalah dan memaksimalkan kemampuan berpikir kritis untuk mendapatkan solusi dari masalah pada dunia nyata. Berdasarkan hasil penelitian tersebut maka dapat disimpulkan bahwa penerapan model PBL dapat meningkatkan keterlibatan dan hasil belajar siswa pada mata pelajaran Kimia pada konsep Kimia Unsur.

Penelitian selanjutnya dilakukan oleh Sumiati (2018) dalam artilek ilmiahnya dengan judul Peningkatan motivasi dan Hasil Belajar dalam Pembelajaran Kimia Melalui Penerapan Model Pembelajaran Problem Based Learning (PBL). Hasil penelitian yang dilakukan di kelas XI IPA 8 SMA N 1 Bantul dengan jumlah 34 siswa melalui dua siklus tindakan tersebut menunjukkan hasil belajar kimia pada konsep Kesetimbangan Kimia didapatkan hasil belajar siswa pada siklus I sebesar 76,5\% dan naik menjadi $94,1 \%$ pada siklus II. Sebanyak $90 \%$ yang merasa tertarik, senang dan termotivasi belajar dengan model PBL. Kesimpulan dari penelitian tersebut adalah penerapan PBL dapat meningkatkan motivasi dan hasil belajar siswa pada mata pelajaran Kimia pada konsep Kesetimbangan Kimia.

Penelitian berikutnya dilakukan oleh Yunita, dkk (2016) dalam makalah seminarnya dengan judul Upaya Meningkatkan Hasil belajar Kimia Siswa Melalui Problem Based Learning pada Konsep Sistem Koloid. Penelitian yang dilakukan melalui dua siklus di kelas XII IPA-1 SMA Negeri 10 Kota Tangerang Selatan pada tanggal 9 Mei s.d 23 Mei 2016 dengan jumlah 38 siswa, pada siklus I, sebanyak 23 siswa atau 60,53\% tuntas belajar dengan rata-rata nilai sebesar 75,47 dan sebanyak 30 siswa atau 78,95\% dengan rata-rata nilai sebesar 83,00 pada siklus II. Kesimpulan dari penelian tersebut adalah bahwa penerapan model pembelajaran PBL dapat meningkatkan hasil belajar siswa pada mata pelajaran Kimia pada konsep Sistem Koloid.

Penelitian selanjutnya dilakukan oleh Puspadewi dan Syahmani (2016) dalam artikel ilmiahnya dengan judul Meningkatkan Hasil Belajar Siswa dengan Model Pembelajaran Problem Based Learning (PBL) Berbantuan Modul dalam Materi Larutan Penyangga. Hasil penelitian yang dilakukan di kelas XI MIA SMA Negeri 1 Banjarmasin yang berjumlah 36 siswa menunjukkan bahwa hasil belajar kognitif siswa pada siklus I sebesar 70,24\% naik menjadi 83,50\% pada siklus II. Nilai afektif siswa pada siklus I sebesar 69,03\% dalam kategori cukup, naik pada siklus II menjadi 83,21 \% dalam kategori baik. Nilai psikomotor siswa pada siklus I sebesar 79,98 dalam kategori terampil, dan pada siklus II naik menjadi 91,85\% dalam kategori sangat baik. Aktivitas siswa pada siklus I sebesar 71,5\% dalam kategori aktif, dan pada siklus II naik pada siklus II menjadi $87 \%$ dalam kategori sangat aktif. Pembelajaran dengan PBL mendapat respon yang sangat positif dari siswa. Kesimpulan dari penelitian tersebut adalah bahwa penerapan model PBL dapat meningkatkan hasil belajar siswa pada mata pelajaran Kimia pada konsep larutan Penyangga

Penelitian selanjutnya oleh Agustina, dkk ( 2015) dalam artikel ilmiahnya dengan judul Penerapan Problem Based Learning (PBL) dengan Penilaian portofolio untuk Meningkatkan Sikap Ilmiah dan Prestasi belajar Siswa pada Materi Sistem Koloid kelas XI MIA SMA Negeri 
1 Sukoharjo Tahun Pelajaran 2015/2016. Hasil penelitian melalui dua siklus tersebut menunjukkan bahwa aspek sikap ilmiah pada prasiklus sebesar $27,5 \%$ naik menjadi $72,5 \%$ pada siklus I dan naik lagi menjadi 97,5\% pada siklus II. Hasil belajar aspek pengetahuan pada siklus I sebanyak 21 siswa atau 52,5\% naik menjadi 38 siswa atau 95\% pada siklus II. Kesimpulan dari penelitian tersebut adalah bahwa penerapan PBL dapat meningkatkan sikap ilmiah dan hasil belajar siswa pada mata pelajaran Kimia pada konsep Sistem Koloid.

Penelitian berikutnya oleh Ariyanti, dkk ( 2013) dalam artikel ilmiahnya dengan judul Penerapan Problem Based Learning (PBL) dengan Penilaian portofolio untuk Meningkatkan Keaktifan dan Prestasi Belajar pada Materi Stoikiometri di SMA N 2 Surakarta Tahun Ajaran 2013/2014. Hasil penelitian melalui dua siklus tersebut menunjukan bahwa pada siklus I sebanyak $87,98 \%$ meningkat menjadi 90,34\% dengan jumlah 32 siswa atau 100\% tuntas belajar pada siklus II. Persentase rata-rata nilai akhir aspek sikap siswa pada siklus I sebesar 70,99\% meningkat menjadi $75,70 \%$ pada siklus II. Kesimpulan dari penelitian tersebut adalah bahwa penerapan model pembelajaran PBL berhasil meningkatkan hasil belajar siswa pada mata pelajaran Kimia pada konsep Stoikiomteri.

Dalam penelitian tersebut juga ada beberapa teori-teori yang mendukung. Menurut Gagne dalam Ariyanti, dkk (2013), belajar adalah suatu proses dimana suatu organisme berubah perilakunya sebagai akibat pengalaman. Ada tiga unsur pokok dalam belajar, yaitu (1) proses, (2) perubahan perilaku, dan (3) pengalaman. Menurut Rusman dalam Baeduriyah (2020) menyatakan bahwa pembelajaran akan lebih bermakna jika siswa diberi kesempatan untuk berpartisipasi dalam berbagai aktivitas pembelajaran. Etherington dalam Ariyanti, dkk (2013) mengemukakan bahwa Problem Based Learning (PBL) adalah model pengajaran yang berpusat pada siswa yang melibatkan pembelajaran melalui pemecahan masalah melalui suatu keadaan.

\section{Pembahasan}

Berawal dari permasalahan yang ditemukan dalam pembelajaran di kelas, dimana didapatkan hasil belajar kimia yang masih rendah pada beberapa konsep kimia, maka guru mencari solusi untuk memecahkan masalah. Guru merefleksi kondisi awal sebelum dilakukan tindakan perbaikan dengan menganalisis model pembelajaran, metode, strategi proses pembelajaran yang digunakan dan faktor lain yang memungkinkan menjadi penyebab rendahnya hasil belajar siswa. Dalam kajian beberapa penelitian yang relevan tersebut, ternyata ditemukan ada kesamaan langkah yang diambil oleh guru untuk meningkatkan hasil belajar kimia, yaitu melakukan Penelitian Tindakan Kelas (PTK) dengan menerapkan salah satu model pembelajaran, yaitu Problem Based Learning (PBL). Menurut Akinoglu \& Tandogan dalam Puspadewi dan Syahmani ( 2016) menyatakan bahwa PBL adalah model pembelajaran yang berpusat pada siswa untuk menghasilkan pembelajaran aktif yang berkemampuan memecahkan masalah dan menjadikan ladang pengetahuan, yang didasarkan pada pemahaman dan pemecahan masalah.

Model PBL sebagai rangkaian aktivitas pembelajaran menekankan pada proses penyelesaian masalah yang dihadapi secara ilmiah, dimulai dengan adanya masalah yang dimunculkan oleh siswa atau guru. Penerapan model pembelajaran PBL pada proses pembelajaran terjadi pembelajaran bermakna, meningkatkan kemampuan berpikir kritis, menimbulkan motivasi internal untuk belajar, dan dapat mengembangkan hubungan interpersonal dalam bekerja kelompk. Siswa belajar memecahkan masalah, mengintegrasikan pengetahuan dan keterampilan secara simultan dan mengaplikasikannya dalam konteks yang relevan. Siswa menjadi lebih aktif dan termotivasi untuk belajar kimia.

Pada penerapan model PBL, pembelajaran menjadi berlangsung dua arah, dari guru ke siswa, dan dari siswa ke guru. Masalah dalam pembelajaran yang dijadikan sebagai fokus pembelajaran dan diselesaikan melalui kerja kelompok menjadikan siswa lebih paham dalam pemecahan masalah dengan menerapkan langkah-langkah metoda ilimah. Dalam proses 
pembelajaran, siswa tidak lagi menjadi obyek belajar, tetapi menjadi pribadi yang dikembangkan potensinya.

Dalam menyampaikan materi pembelajaran guru menggunakan media pembelajaran sehingga siswa menjadi lebih mudah memahami konsep kimia menjadi nyata. Guru mengkombinasikan metode pembelajaran dengan media pembelajaran yang sesuai dengan materi yang dibahas dalam kelompok-kelompok diskusi. Dalam pembelajaran kooperatif, siswa mendapatkan pengalaman baru dalam pemecahan masalah sehingga meningkatkan kemampuan dalam berkomunikaasi. Menurut Nur \& Wikandari dalam Suprihatiningrum (2013 : 192) mengatakan bahwa kelompok kooperatif dapat digunakan untuk memecahkan sebuah masalah kompleks. Dalam proses pembelajaran guru berfungsi sebagai motivator, fasilitator, dan kontrol. Proses pembelajaran dengan menerapkan PBL meningkatkan aktivitas guru dan siswa dalam proses pembelajaran.

Guru menerapkan model pembelajaran, PBL karena memiliki beberapa keunggulan dalam pemecahan masalah, antara lain: (1) menantang kemampuan siswa (2) meningkatkan aktivitas pembelajaran siswa, (3) membantu siswa bagaimana mentrasfer pengetahuan untuk memahami masalah dalam kehidupan nyata, (4) membantu siswa mengembangkan pengetahuan barunya, (5) bertanggungjawab dalam pembelajaran yang mereka lakukan, dan (6) siswa merasa senang dan menyukai penerapan pembelajaran PBL. Pembelajaran kimia merupakan pembelajaran yang sistematis, tersusun teratur dan saling barkaitan, sedangkan pembelajaran PBL merupakan model pembelajaran yang komprehensif, dimana di dalamnya terdapat unsur menemukan masalah sekaligus memecahkan masalah.

Berdasarkan hasil penelitian menunjukkan bahwa hasil belajar siswa yang materi pembelajarannya diajarkan melalui penerapan PBL lebih tinggi dibandingkan dengan penerapan model konvensional. Jadi dapat disimpulkan bahwa penerapan model pembelajaran Problem Based Learning (PBL) dapat meningkatkan hasil belajar siswa, khususnya pada mata pelajaran Kimia. Hal ini sejalan dengan pendapat Ridwan dalam Suarsani (2019) yang menyatakan bahwa PBL dapat meningkatkan hasil belajar siswa pada aspek kognitif, afektif dan psikomotorik.

\section{KESIMPULAN}

Berdasarkan literatur review pada sembilan penelitian yang relevan terdapat kesamaan hasil penelitian, yaitu bahwa penerapan model pembelajaran Problem Based Learning (PBL) dapat meningkatkan hasil belajar siswa, khususnya pada mata pelajaran Kimia. Penerapan model PBL menyebabkan siswa dapat mengembangkan sikap ilmiah, aktif dalam proses pembelajaran, mengembangkan hubungan interpersonal dan motivasi dalam bekerja kelompok, menimbulkan motivasi internal untuk belajar, dan dapat meningkatkan aktivitas guru dan siswa dalam proses pembelajaran. Penerapan model PBL dapat meningkatkan hasil belajar siswa pada aspek kognitif, afektif dan psikomotorik.

Berdasarkan hasil penelitian ini, penulis memberikan saran kepada guru, khususnya guru kimia untuk menerapkan model pembelajaran PBL dalam menyampaikan materi kimia karena dapat meningkatkan hasil belajar siswa. Penerapan model PBL ini perlu dipersiapkan sebaik-baiknya sehinga siswa dapat menyelesaikan tahap-tahap pembelajaran dengan baik.

\section{DAFTAR PUSTAKA}

Agustina, R.P, Ashadi \& Mulyani, B. (2015). Penerapan Problem Based Learning (PBL) dengan Penilaian Portofolio untuk Meningkatkan Sikap Ilmiah dan Prestasi belajar Siswa pada Materi Sistem Koloid Kelas XI MIA SMA Negeri 1 Sukoharjo Tahun Pelajaran 2015/2016. Jurnal Pendidikan Kimia (JPK), Vol. 6, N0. 2 : 144-153.

Ariyanti, P, Martini, K.S \& Agustina, E.S.W. (2013). Penerapan Problem Based Learning (PBL) dengan Penilaian Portofolio untuk Meningkatkan Keaktifan dan Prestasi Belajar pada Materi Stoikiometri di SMA N 2 Surakarta Tahun Ajaran 2013/2014. Jurnal Pendidikan Kimia (JPK), Vol. 6, N0. 2 : 1-9 
Baeduriyah. (2020). Penerapan Problem Based Learning Berbasis TPACK untuk Meningkatkan Hasil Belajar Siswa Kelas X SMKN 3 Mataram pada Pokok Bahasan Ikatan Kimia. PPG Daljab Angkatan 2 Pendidikan Kimia Universitas Mataram.

Jami. (2020). Meningkatkan Hasil Belajar Kimia Kelas XI MIA MAN 1 Tanjung Jabung Timur dengan Menerapkan Model pembelajaran Problem Based Learning. Journal Evaluation in Education (JEE) Vol. 1, No 2, April 2020, pp. 42-49.

Puspadewi, A dan Syahmani. (2016). Meningkatkan Hasil Belajar Siswa dengan Model Pembelajaran Problem Based Learning (PBL) Berbantuan Modul dalam Materi Larutan Penyangga. QUANTUM, Jurnal Inovasi Pendidikan Sains, Vol. 7, No 1 : 19-26

Sardiman. (2012). Interaksi dan Motivasi Belajar Mengajar. Jakarta, Raja Grafindo Persada.

Suarsani, G.A. (2019). Meningkatkan Hasil Belajar Kimia dengan Materi Pokok Kimia Unsur Melalui Penerapan Model Pembelajaran Problem Based Learning. JP2, Vol. 2, No. 1,

Sumiati, (2018). Peningkatan motivasi dan Hasil Belajar dalam Pembelajaran Kimia Melalui Penerapan Model Pembelajaran Problem Based Learning (PBL). JURNAL IDEGURU, Vol. 3, No. 1, Mei 2018. Diakses dari:

Suprihatiningrum, J. (2013). Strategi Pembelajaran Teori dan Aplikasi. Jogjakarta. Ar-Ruzz Media

Yani, L.R. (2020). Penerapan Model Pembelajaran PBL untuk Meningkatkan Hasil Belajar Siswa pada Materi Ikatan Kimia di SMA Negeri 5 Takengon. Skripsi Mahasiswa Fakultas Tarbiyah dan Keguruan Prodi Pendidikan Kimia.

Yunita, L, Kusmiati, R dan Afria,D.N. (2016). Upaya Meningkatkan Hasil belajar Kimia Siswa Melalui Problem Based Learning pada Konsep Sistem Koloid. Seminar Nasional Pendidikan IPA-Biologi FITK UIN Syarf Hidayatullah Jakarta 